\title{
PERAN AKTIF WANITA DALAM PENINGKATAN PENDAPATAN RUMAH TANGGA MISKIN: STUDI KASUS PADA WANITA PEMECAH BATU DI PUCANGANAK KECAMATAN TUGU TRENGGALEK*
}

\author{
Sugeng Haryanto \\ Program D3 Keuangan dan Perbankan Universitas Merdeka Malang \\ Email: p3et@yahoo.com
}

\begin{abstract}
This research explain how women share actively in the effort increasing earnings of the household. This research done with taking sample at the stone crusher women in Kecamatan Tugu Kabupaten Trenggalek. Women have potency in giving contribution of earnings of household, especially impecunious household. In impecunious household, women household member plunge to job market for adding earnings household felt insufficient. Women contribution can be told as safety valve or supporter for impecunious household to fulfill everyday basic need. This research aim 1) for analyzing contribution of earnings of stone crusher worker women to earnings of family, 2) to know usage of earnings of stone crusher worker women, 3) to know in working which poured by stone crusher worker women. Research finding indicate that women who work as stone crusher have enough significant earnings contribution to earnings of family.
\end{abstract}

Keywords: stone crusher women, earning contribution, outpouring time

\section{PENDAHULUAN}

Fenomena yang menarik pada rumah tangga miskin dalam mempertahankan hidup dengan tingkat kehidupan yang layak, yaitu pertama pada sisi pengeluaran melakukan penghematan pada pengeluaran yang dirasakan dapat ditunda, pengeluaran-pengeluaran yang berkaitan dengan transportasi sedapat mungkin dihindari atau dikurangi. Kedua, pada sisi pendapatan rumah tangga pada rumah tangga miskin telah memaksa mereka untuk melakukan pengoptimalan pendapatan melalui pengerahan sumber daya ekonomi yang dimiliki. Upaya ini dilakukan dalam upaya untuk tetap dapat mempertahankan tingkat kesejahteraan atau kehidupan yang layak. Namun demikan upaya ini tidak semuanya mampu untuk dapat mempertahankan pada tingkat kehidupan yang layak.

Dalam keluarga miskin, pada umumnya seluruh sumber daya manusia dikerahkan untuk memperoleh penghasilan, sebagai upaya pemenuhan pokok sehari-hari. Oleh sebab itu dalam keluarga miskin menganggur merupakan sesuatu yang mahal, karena anggota keluarga lain yang bekerja atau menjadi beban tanggungan anggota rumah tangga lain. Mereka tidak sempat menganggur dan

\footnotetext{
* Penelitian ini merupakan penelitian SKW yang dibiayai oleh DIKTI tahun 2007
} 
mereka bersedia melakukan pekerjaan apapun, terutama sektor informal yang tidak membutuhkan keahlian tertentu, mudah untuk dimasuki, luwes, dan tidak membutuhkan modal yang besar.

Berkaitan dengan pengerahan sumber daya ekonomi yang dimiliki rumah tangga miskin, maka telah menuntut wanita sebagai istri untuk dapat menopang ketahanan ekonomi keluarga. Kondisi demikian merupakan dorongan yang kuat bagi wanita untuk bekerja di luar rumah. Dalam beberapa tahun terakhir ini keterlibatan wanita pada sektor publik menunjukkan angka yang terus meningkat. Hal ini menunjukkan bahwa motivasi wanita untuk bekerja di sektor publik semakin tinggi.

Wanita pada rumah tangga miskin, ratarata mempunyai tingkat pendidikan yang relatif rendah karena kondisi ekonomi yang melatarbelakanginya. Wanita ini masuk ke pasar kerja dengan tingkat pendidikan rendah dan ketrampilan rendah. Wanita dengan tingkat pendidikan dan ketrampilan yang rendah inilah yang justru banyak masuk ke lapangan kerja, terutama pada sektor informal dengan motivasi menambah pendapatan keluarga.

Di daerah Pucanganak Kecamatan Tugu Trenggalek banyak dijumpai keluarga yang bekerja sebagai pemecah batu, selain sebagai petani. Dengan kondisi tanah yang berbukit mengakibatkan areal pertanian menjadi terbatas, mereka banyak bekerja sebagai pemecah batu yang berada di sekitar sungai di daerah tersebut. Pekerjaan sebagai pemecah batu menjadi dominan karena tingkat keterampilan yang dimiliki sangat terbatas dan pendidikan yang rata-rata memang rendah.

Penelitian ini bertujuan untuk: 1) untuk mengetahui kontribusi pendapatan pekerja wanita pemecah batu terhadap pendapatan keluarga, 2) Untuk mengetahui penggunaan pendapatan pekerja wanita pemecah batu, 3) Untuk mengetahui curahan waktu kerja pekerja wanita pemecah batu.

Tinjauan pustaka dalam penelitian ini sebagai berikut:

\section{Gender Inequality}

Gender diartikan merupakan konstruksi sosial-kultural yang membedakan karakteristik maskulin dan feminin. Gender membagi atribut dan pekerjaan menjadi maskulin dan feminin. Secara realitas sosial menunjukkan bahwa pembagian peran berdasarkan gender melahirkan keadaan yang tidak seimbang, di mana wanita menjadi tersubordinasi oleh laki-laki yang disebut sebagai ketimpangan gender.

Analisis gender dalam kegiatan ekonomi todak dapat dipisahkan dari analisis tentang keluarga. Ekonomi dan keluarga merupakan dua lembaga yang saling berhubungan sekalipun tampak keduanya terpisah satu sama yang lainnya. Ketidakseimbangan berdasarkan gender (Gender Inequality) mengacu pada ketidakseimbangan pada akses ke sumber-sumber yang langka dalam masyarakat. Sunmber yang penting yang ada di masyarakat ini antara lain meliputi kekuasaan atasmaterial, jasa, prestise, peran dalam masyarakat, kesempatan memperoleh pendidikan, kesempatan memperoleh pekerjaan dan sebagainya. Pendapat tentang ketimpangan gender ini tampaknya kurang memperhatikan aspek sosial budaya yang mengkonstruksi terjadinya ketimpangan tersebut. 


\section{Pekerja Wanita dan Motivasi Kerja}

Wanita mempunyai potensi dalam memberikan kontribusi pendapatan rumah tangga, khususnya rumah tangga miskin. Dalam rumah tangga miskin anggota rumah tangga wanita terjun ke pasar kerja untuk menambah pendapatan rumah tangga yang dirasakan tidak cukup.

Peningkatan partisipasi wanita dalam kegiatan ekonomi karena: pertama, adanya perubahan pandangan dan sikap masyarakat tentang sama pentingnya pendidikan bagi kaum wanita dan pria, serta makin disadarinya perlunya kaum wanita ikut berpartisipasi dalam pembangunan, kedua, adanya kemauan wanita untuk bermandiri dalam bidang ekonomi yaitu berusaha membiayai kebutuhan hidupnya dan mungkin juga kebutuhan hidup dari orang-orang yang menjadi tanggungannya dengan penghasilan sendiri. Kemungkinan lain yang menyebabkan peningkatan partisipasi wanita dalam angkatan kerja adalah makin luasnya kesempatan kerja yang bisa menyerap pekerja wanita, misalnya munculnya kerajinan tangan dan industri ringan.

Wanita mempunyai potensi dalam memberikan kontribusi pendapatan rumah tangga, khususnya rumah tangga miskin. Dalam rumah tangga miskin anggota rumah tangga wanita terjun ke pasar kerja untuk menambah pendapatan rumah tangga yang dirasakan tidak cukup. Hasil penelitian yang dilakukan Mariun (2004) menunjukkan dari 53,44 persen perempuan yang bekerja, 72,79 persen adalah pekerja tetap, artinya perempuan mempunyai kepastian dalam memperoleh pendapatan. Yuniarti dan Haryanto (2005) pendapatan para pekerja wanita pada industri sandang mempunyai kontribusi yang signifi- kan terhadap peningkatan pendapatan keluarga. Kontribusi perempuan dapat dikatakan sebagai katup pengaman (savety valve) atau penopang bagi rumah tangga miskin untuk memenuhi kebutuhan dasar sehari-hari.

Wanita Indonesia terutama di pedesaan sebagai sumber daya manusia cukup nyata partisipasinya khususnya dalam memenuhi fungsi keluarga dan rumah tangga bersama pria. Beberapa hasil penelitian menunjukkan peran serta wanita dalam berbagai industri di beberapa daerah cukup besar dan menentukan, dengan pengelolaan usaha yang bersifat mandiri (Lestari, dkk: 1997).

Potensi yang dimiliki wanita untuk menopang ekonomi keluarga memang cukup besar. Namun demikian wanita tidak menonjolkan diri atau mengklaim bahwa mereka menjadi penyangga utama ekonomi keluarga. Temuan penelitian yang dilakukan oleh Wibowo (2002) pada pedagang tradisional di Semarang menunjukkan bahwa kaum wanita pedagang tetap tidak ingin menonjolkan diri atau mengklaim bahwa aktivitasnya sebagai pedagang adalah utama (pokok), melainkan hanya sekedar mendukung kegiatan suami, waluapun tidak menutup kemungkinan penghasilan mereka jauh lebih besar daripada apa yang diperoleh oleh suami mereka.

Gambaran mengenai pembagian kerja rumah tangga berdasarkan jenis kelamin tersebut merupakan sebagian kecil bukti yang mencerminkan ketidak seimbangan peran produktif dan peran reproduktif antara wanita dan pria. Gambaran seperti ini banyak terdapat di berbagai masyarakat, dan keadaan seperti ini tampak kurang menguntungkan wanita dalam meraih kesempatan melakukan kegiatan-kegiatan produktifnya. 


\section{Wanita dan Kegiatan Sosial}

Dalam kehidupan bermasyarakat interaksi antara keluarga merupakan bagian yang sangat penting. Hubungan antaranggota keluarga dalam kehidupan bermasyakat dalam bentuk seperti pertemuan rukun tetangga (RT), Dasa wisma, pertemuan yang bersifat kegamaan seperti tahlilan merupakan hal dipandang sangat penting dalam kehidupan bermasyarakat.

Pertemuan-pertemuan dalam rangka kehidupan sosial bermasyarakat tentunya akan merupakan suatu bentuk penyisihan tersendiri bagi seseorang yang harus mencari nafkah jauh dari tempat tinggalnya. Bagi keluarga yang relatif miskin, seringkali wanita sebagai seorang ibu dituntut untuk juga bekerja. Bagi wanita yang bekerja seperti ini tentunya pengaturan waktu akan sangat penting sekali antara bekerja dengan kegiatan sosial kemasyarakatan.

Ketika seseorang tidak mengikuti kegiatan sosial kemasyarakatan, maka seringkali seseorang akan merasa diasingkan dari lingkungannya. Hal ini tentunya bagi masyarakat yang miskin yang rata-rata tinggal di suatu perkampungan merupakan beban yang sangat berat.

\section{Pendapatan keluarga wanita}

Sumber utama pendapatan bagi pekerja wanita adalah upah dan tunjangan-tunjangan kesejahteraan lain yang diperoleh oleh pekerja. Sebagaimana diketahui regulasi pemerintah untuk mengatur UMR tetapi kondisi demikian tentunya akan sangat sulit diterapkan pada industri-industri kecil atau menengah dimana jam kerja dalam sehari masih jauh di bawah standar jam kerja. Upah dalam industri kecil dan menengah semata- mata mengandalkan mekanisme harga. Pekerja wanita di industri kecil dan menengah di kota akan membandingkan dengan upah yang diterimanya sebagai pekerja pada sektor lain pada wilayah opportunity-nya. Maksudnya adalah level-level jabatan pekerjaan yang tingkat kemudahan memperolehnya.

Beberapa penelitian seperti Ardjani (2003) di IRT sandang merupakan persepsi pekerja terhadap upah pada wilayah opportunity pekerjaaan itu sendiri. Upah yang diperoleh pekerja IRT pada IRT sandang menunjukkan lebih tinggi dibandingkan dengan upah yang diperoleh pada IRT bidang lain. Temuan ini, walaupun belum sangat meyakinkan tetapi merupakan suatu surprise.

Ardjani (2003) menemukan bahwa 20,7 persen menyatakan IRT lebih tinggi, 63 persen menyatakan sama saja dan hanya 16 persen yang menyatakan lebih kecil upah yang mereka terima dari IRT dibandingkan dengan upah buruh industri yang sama yang diintervensi pemerintah. UMR pada tahun penelitian Rp1.350,- per hari. Rata-rata penerimaan IRT sandang di Baliu ntuk bordir, konveksi dan tenun adalah Rp8.786,- Rp11.180,- dan Rp10.175,- perminggu.Harga beras Rp500,perkilogram pada saat penelitian.

Penelitian di IRT yang dilakukan oleh Ken (1994) di Sulawesi menunjukkan pendapatan buruh lebih rendah dibandingkan dengan umur dan juga upah industrial. Keadaan ini diterima dengan dikonversi dengan kombinasi berbagai pendapatan, juga karena dapat dilakukan di desa/dekat rumah serta pendapatan non uang.

\section{Sektor Informal}

Sektor informal merupakan unit usaha yang berskala kecil yang menghasilkan dan 
mendistribusikan barang dan jasa dengan tujuan menciptakan kesempatan kerja bagi dirinya sendiri Sektor informal ini sering disebut juga dengan aktivitas informal, kesempatan kerja yang diciptakan (self employment), ekonomi di bawah tanah (underground economy), causal work, shadow economy (Subarsono, 1998).

Menurut Tobing (2002) umumnya yang terlibat dalam sektor informal adalah berpendidikan rendah, miskin tidak terampil dan kebanyakan para migran, kurang mampu mengartikulasikan dan menetapkan kebutuhannya. Karena itu cakrawala mereka terbatas untuk memberi kesempatan kerja dan menghasilkan pendapatan langsung bagi dirinya sendiri, tidak memaksimasi profit. Berkaitan dengan memaksimasi profit tidak selamanya benar, sebab sebagian besar sektor informal ternyata mempunyai falsafah profit motive (Effendi, 1997).

Aktivitas sektor informal ditandai dengan: a) mudah untuk memasukinya, b) bersumber pada sumber daya lokal, c) usaha milik sendiri d) operasinya dalam skala kecil, e) padat karya dan teknologinya bersifat adaptif, f) ketrampilan diperoleh dari luar sistem sekolah, g) tidak tersentuh langsung oleh regulasi pemerintah, h) pasarnya bersifat kompetitif (Gilbert dan Glugler: 1996: 96).

Perspektif pelaku ekonomi dapat dibedakan kedalam dua kelompok besar, yaitu sektor usaha formal dan sektor informal. Sektor formal diasosiasikan dengan usaha baik kecil, menengah maupun besar yang memiliki badan hukum dan menjadi bagian dari sistem ekonomi formal. Sektor informal adalah sektor ekonomi yang ditandai dengan ketiadaan badan hukum serta ruang gerak yang di luar kerangka aturan yang legal.
Usaha sektor informal adalah uasaha mikro dan juga usaha kecil (Binaswadaya, 2002).

Subarsono (1996) mengemukakan karakteristik sektor informal adalah: a) sektor informal ini mudah dimasuki, b) tidak memerlukan ijin untuk beroperasi, c) menggunakan tehnologi sederhana dan padat tenaga kerja d) tidak ada akses keinstitut keuangan formal, e) beroperasi dalam skala kecil dan biasanya milik keluarga, f) unit usahanya tidak terorganisir, g) kesempatan kerja di sektor ini tidak terproteksi sebab tidak diatur oleh peraturan pemerintah.

Mengapa seseorang memasuki sektor informal? Ada faktor yang menyebabkan sektor informal muncul, misalnya karena proses memperoleh kesempatan untuk memasuki sektor formal ternyata memerlukan biaya transaksi yang terlalu tinggi bagi sebagian besar masyarakat urban dan rural. Motif usaha seseorang masuk sektor informal adalah alasan ekonomi (Winarno, 1996). Sektor informal saat ini semakin berkembang, sebagian akibat dari keterpurukan sektor formal, banyak angkatan kerja yaang terpental dari sektor formal (Wahyudi, 2001). Sektor informal telah mampu menjadi katup pengaman bagi perkembangan angkatan kerja yang setiap tahun terus mengalami peningkatan (Haryanto, 2000) .

Keberadaan sektor informal saat ini menjadi sangat penting karena beberapa faktor. Sektor informal selain sebagai penyedia lapangan kerja, juga keberadaan dan kemampuan sektor informal ini bertahan di perkotaan tanpa bantuan dari pemerintah adalah karena kebutuhan akan berbagai macam pruduk dan jasa yang dihasilkan oleh sektor informal ini. Selain itu sektor formalpun membutuhkan keberadaan sektor informal ini dan sektor informal dan formal saling 
berkaitan dan melengkapi. Peran sektor informal sebagai basis ekonomi kerakyatan di beberapa kawasan kota besar memegang fungsi strategis sebagai sector resccue dan penyangga yang menyelamatkan subsistensi sebagian besar penduduk yang hidup di bawah urban stress (Wahyudi, 2001).

\section{METODE PENELITIAN}

\section{Definisi Operasional Variabel}

1. Pendapatan rumah tangga, yang dimaksud dengan pendapatan rumah tangga dalam penelitian ini adalah jumlah rupiah yang diperoleh oleh istri dan suami dari bekerja, yang diukur dengan rupiah ratarata perminggunya.

2. Pekerja wanita, yang dimaksud dengan pekerja wanita dalam penelitian ini adalah wanita yang bekerja sebagai pemecah batu kali di daerah Pucanganak Kecamatan Tugu Trenggalek.

3. Peran aktif wanita, yang dimaksud engan peran aktif wanita dalam penelitian ini adalah curahan waktu rata-rata perhari yang diberikan wanita untuk bekerja sebagai pemecah batu untuk memperoleh pendapatan dalam bentuk rupiah.

4. Rumah tangga miskin, yang dimaksud dengan rumah tangga miskin dalam penelitian diguna indikator rumah tangga penerima Bantuan Tunai Langsung (BLT).

\section{Jenis data}

Jenis data dalam penelitian ini adalah data primer, yang berupa data pekerja wanita sebagai pemecah batu di Desa Pucang anak Kecamatan Tugu Trenggalek, Waktu bekerja, kegiatan sosial kemasyarakatan, pendapatan dari hasil penjualan batu pecahan, penda- patan seluruh keluarga, jumlah anak dan data lainnya.

\section{Populasi dan sampel}

Populasi dalam penelitian ini adalah wanita pemecah batu di Desa Pucanganak Kecamatan Tugu Trenggalek. Sampel diambil secara diambil dengan menggunakan metode purposive random sampling, yaitu sebagai berikut: Menentukan pekerja wanita sebaga pemecah batu yang yang berada di beberapa perdukuhan berada di Daerah Pucanganak, kemudian menentukan pekerja waniat sebagai pemecah batu yang menjadi sampel secara random.

\section{Lokasi Penelitian}

Lokasi penelitian dilakukan di Desa Pucanganak Kecamatan Tugu Trenggalek. Penentuan lokasi ini didasari bahwa daerah ini tanahnya relatif kurang subur dengan topografi yang berbukit-bukit serta tanah pertaniannya relatif sempit. Sehingga meraka banyak memfaatkan potensui alam berupa batuan di sungai untuk dijual sebagai bahan bangunan.

\section{Teknik Pengumpulan Data}

Teknik pengumpulan data dilakukan melalui:

- Kuesioner terbimbing, yaitu penyebaran kuesioner dengan memberikan bimbingan secara langsung kepada responden. Hal ini dilakukan karena mayoritas responden yang kemampuan membaca dan menulisnya yang rendah.

- Wawancara mendalam (in-depth interviewing, wawancara ini dilakukan untuk memperdalam informasi dari para responden 
- Observasi langsung, dua metode ini (wawancara secara mendalam dan observasi langsung) sejalan dengan teknik observasi pasif.

\section{Teknik Analisis Data}

Teknik analisis data yang digunakan dalam penelitian ini adalah dengan analisis deskriptif kuantitatif, yaitu dengan melakukan penalaran logis. Data temuan lapangan disusun secara sistematis yang menunjukkan bagaimana peran aktif wanita dalam peningkatan ekonomi rumah tangga.

\section{HASIL PENELITIAN DAN PEMBAHASAN}

Usia para wanita pemecah batu ini di atas 25 tahun, bahkan ada yang usianya sudah lanjut di atas 60 tahun. Wanita pemecah batu yang usianya antara 26-40 tahun sebanyak 20 persen, 41 tahun sampai dengan 50 tahun 30 persen dan 51 tahun sampai dengan 60 tahun 30 persen serta 10 persen telah berusia di atas 60 tahun.

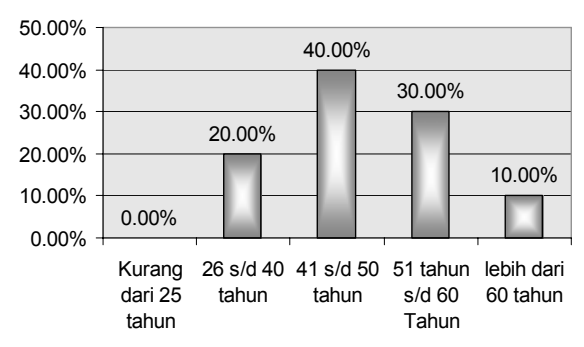

Sumber: Data primer

\section{Gambar 1. Usia Wanita Pemecah Batu}

Dari pekerjaan yang mereka lakukan, dimana pekerjaan ini relatif tidak mengandalkan keterampilan dan sering orang menganggap merupakan pekerjaan kasar dan berat, dan usia responden maka pendidikana para wanita ini rata-rata rendah dan bahkan tidak pernah mengenyam dunia pendidikan formal. Hampir 97 persen hanya maksimum berpendidikan SD, dimana 33.33 persen tidak pernah sekolah dan 30 persen pernah sekolah di SD dan 33.33 lulus SD. Sedangkan yang pernah dekolah sampai SMP hanya 3.33 persen.

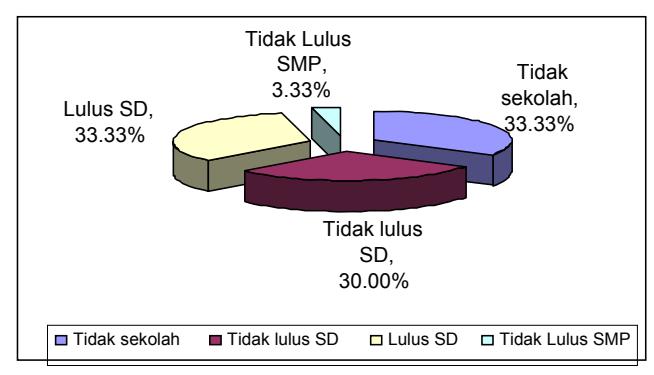

Sumber: Data primer

\section{Gambar 2. Pendidikan Wanita Pemecah Batu}

Pekerjaan suami para pemecah batu cukup bervariasi, yaitu sebagai petani atau buruh tani sebanyak 33,3 persen, sebagai tukang atau kuli bangunan 33,3 persen dan sebagai pemecah batu juga sebanyak 20 persen sedangkan sisanya adalah lainnya. Sebagai petani dan buruh tani mereka biasanya pada saat tidak ada pekerjaan di sawah akan bekerja juga sebagai pemecah batu demikian juga halnya untuk pekerjaan sebagai kuli bangunan.

Pekerjaan suami menunjukkan bahwa rata-rata pekerjaan mereka merupakan petani dan atau pekerjaan-pekerjaan yang tidak menuntut keahlian atau tingkat pendidikan tertentu. Hal ini tidak terlepas dari kondisi keluarga mereka yang rata-rata berasal dari petani yang kurang mampu, sehingga berdampak pada tingkat pendidikan dan keahlian yang mereka miliki. Hal ini selanjutnya 
akan berpengaruh pada pekerjaan yang mereka lakukan atau mereka peroleh.

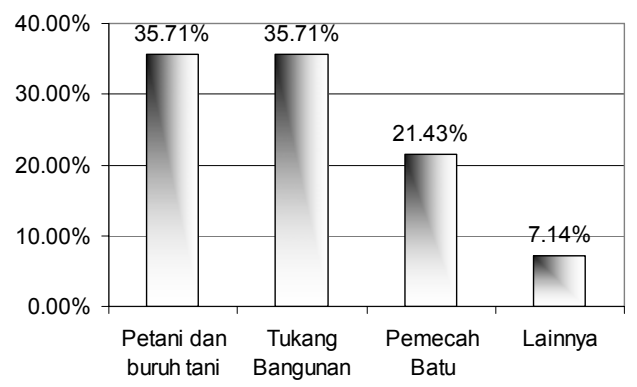

Sumber: Data primer

Gambar 3. Pekerjaan Suami Wanita Pemecah Batu

\section{Kontribusi Pendapatan Pekerja Wanita Pemecah Batu terhadap Pendapatan Keluarga}

Pendapatan merupakan uang yang diterima seseorang karena seseorang bekerja. Pendapatan keluarga terdiri dari pendapatan yang diperoleh oleh suami yang bekerja ditambah dengan pendapatan yang diperoleh karena istri yang bekerja.

Besarnya pendapatan suami para pekerja wanita ini disajikan pada tabel 1. Pendapatan ini dihitung selama satu minggu. Pendapatan suami yang besarnya kurang dari Rp40.000 sebanyak 12 orang dan antara Rp40.000 sampai dengan Rp60.000 sebanyak 13 orang. Banyak pendapatan yang berkisar diangka tersebut dikarenakan pekerjaan yang sifatnya dipertanian dan bangunan relatif tidak dapat dipastikan sepanjang waktu. Sehingga responden membuat pendapatan tersebut adalah rata-ratanya.
Tabel 1. Rata-rata Pendapatan Suami perminggu

\begin{tabular}{lc}
\hline \multicolumn{1}{c}{ Pendapatan } & Jumlah \\
\hline Kurang dari 40.000 & 12 \\
Rp $40.000-\leq 60.000$ & 13 \\
Rp $61.000-\leq 80.000$ & 3 \\
Rp $81.000-\leq 100.000$ & 0 \\
Lebih dari 100.000 & 0 \\
\hline
\end{tabular}

Pendapatan suami yang relatif tinggi, yaitu lebih dari Rp 61.000 karena mereka merasakan suami mereka bekerja relatif kontinue. Jam kerja suami para pekerja wanita rata-rata perminggu berkisar antara 3 sampai dengan 5 jam sebanyak 5 orang sedangkan yang bekerja antara 5 sampai dengan 8 sebanyak 20 orang dan lebih dari 8 jam sebanyak 5 orang. Rendahnya jumlah jam kerja ini mereka rasakan karena untuk yang bekerja di sektor pertanian pekerjaannya tidak rutin sepanjang waktu.

Sedangkan yang bekerja di sektor bangunan juga merasa tidak kontinyu. Rendahnya jumlah jam kerja ini berpengaruh pada tingkat pendapatan yang mereka peroleh. Selain sumber pendapatan yang berasal dari suami dan istri ada juga sumber pendapatan yang berasal dari anak. 67 persen menyatakan ada sumber pendapatan yang berasal dari anak, sedangkan 33 persen tidak ada sumber pendapatan selain dari suami dan istri.

Besarnya pendapatan yang diperoleh oleh wanita yang bekerja sebagai pemecah batu rata-rata perminggu rata-rata sebesar 53,57 persen berkisar Rp40.000 Rp60.000. Tingkat pendapatan pekerja wanita pemecah batu secara keseluruhan disajikan pada Gambar 4. 


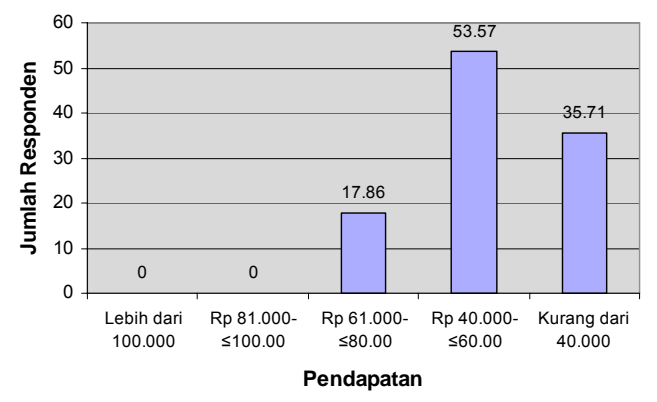

\section{Gambar 4. Tingkat Pendapatan Wanita Pemecah Batu Perminggu}

Dilihat dari tingkat pendapatan yang diperoleh oleh istri yang bekerja sebagai pemecah batu menunjukkan relatif cukup tinggi dengan untuk ukuran didesa. Hal ini mengingat pekerjaan tersebut berada di dekat rumah, sehingga sang istri tidak harus meninggalkan pekerjaan-pekerjaan rumah. Artinya pekerjaan rumah masih dapat dilakukan sambil bekerja untuk menambah pendapatan kelaurga. Para wanita ini menganggap pekerjaan sebagai pemecah batu sebagai bentuk ketimbang ganggur neng omah.

Tanggapan suami terhadap istri yang bekerja di luar rumah ini dianggap sebagai suatu yang wajar bagi mereka. Hal ini mengingat pekerjaan di luar rumah tersebut lokasi tidak jauh dari rumah, bahkan ada yang hanya terletak dihalaman rumahnya. Sehingga sang suami juga tidak takut jika sang istri meninggalkan pekerjaan-pekerjaan domestiknya.

Pendapatan yang diperoleh oleh pekerja wanita tersebut menurut mereka dirasakan sudah cukup. Responden yang menyatakan pendapatan tersebut cukup sebesar 73,33 persen dan 16 persen memadai, hanya 10 persen menyatakan masih kurang.

Pendapatan yang dirasakan sudah memadai atau cukup tersebut mereka orang desa yang mempunyai rasa nrima, selain kebutuhan mereka yang tidak begitu besar. Kebutuhan yang tidak begitu besar tersebut karena anak-anak mereka yang sudah bekerja atau anak mereka masih kecil, sehingga kebutuhannya juga belum begitu besar. Tabel 2. Pendapatan yang Diperoleh Wanita
Pekerja

\begin{tabular}{lrr}
\hline Keterangan & Jumlah & Prosentase \\
\hline Sudah memadai & 5 & $16.67 \%$ \\
Cukup & 22 & $73.33 \%$ \\
Kurang & 3 & $10.00 \%$ \\
& 30 & $100 \%$ \\
\hline
\end{tabular}

Sumber Data Primer

Dalam masyarakat bawah atau miskin anggota keluarga merupakan suatu sumber daya yang harus dimanfaatkan untuk dapat bekerja, baik itu untuk menyelesaikan pekerjaaan rumah tangga maupun pekerjaan yang mempunyai potensi untuk menambah ekonomi atau pendapatan keluarga. Walaupun pekerjaan-pekerjaan yang hanya menghasilkan upah atau pendapatan yang rendah. Hal ini bagi keluarga miskin dianggap sebagai suatu yang sudah menguntungkan. Karena adanya anggapan ketimbang nganggur ono ngomah. Pada keluarga yang miskin biasanya pekerjaan-pekerjaan domestik cenderung hanya terbatas pada memasak untuk keluarga dan mencuci pakaian serta membersihkan rumah, hal itu dapat dilakukan pagi hari atau bahkan anak-anak mereka sudah dapat membantu untuk menyelesaikan pekerjaan domestik tersebut. 


\section{Penggunaan Pendapatan Pekerja Wanita Pemecah Batu}

Pendapatan yang diterima oleh suami dan istri tidak ada pemisahan, dimana pendapatan suami selalu diberikan kepada istri. Pendapatan yang mereka peroleh mereka anggap sebagai pendapatan keluarga. Sehingga penggunaan pendapatan juga merupakan penggunaan atau belanja untuk kebutuhan keluarga. Penggunaan untuk kebutuhan keluarga tersebut, antara lain untuk mencukupi kebutuhan pokok sehari-hari, untuk kebutuhan sekolah dan juga untuk kebutuhan yang sifatnya sosial, seperti arisan, bowo (menyumbang orang yang punya hajatan).

Tabel 3. Penggunaan Pendapatan Keluarga

\begin{tabular}{lc}
\hline $\begin{array}{c}\text { Keterangan Penggunaan } \\
\text { Penggunaan Pendapatan }\end{array}$ & Jumlah \\
\hline Kebutuhan rumah tangga & 30 \\
Biaya sekolah anak & 20 \\
Arisan dan sosial lainnya & 30 \\
\hline
\end{tabular}

Penggunaan pendapatan yang terbesar rata-rata untuk mencukupi kebutuhan rumah tangga sehari-hari. Sedangkan biaya sekolah hanya temporer, yaitu setiap bulan untuk membayar SPP, sedangkan uang saku anak juga tidak begitu besar. Selain itu juga digunakan untuk kebutuhan arisan di lingkungannya masing-masing, untuk menyelenggarakan kegiatan kendurian juga biasanya mereka lakukan.

Dilihat dari distribusi penggunaan pendapatan istri atau wanita menunjukkan bahwa belum ada atau tidak banyak wanita yang menggunakan penghasilannya untuk memenuhi kebutuhannya sendiri secara pribadi. Penghasilan mereka digunakan untuk memenuhi kebutuhan keluarga secara bersama. Hal ini sangat terkait dengan kebiasaan yang ada di masyarakat terutama pedesaan bahwa tanggung jawab untuk mengatur rumah tangga merupakan tanggungjawab wanita atau istri.

\section{Curahan Waktu Kerja Pekerja Wanita Pemecah Batu}

Para wanita pemecah batu ini rata-rata bekerja sebagai pemecah batu sehari selama 5 sampai dengan 8 jam (73,33 persen). Namun demikian waktu yang dialokasikan tersebut relatif flrksibel. Hal ini karena pekerjaan tersebut tidak menuntut jam yanbg pasti, selain merupakan pekerjaannya sendiri. (Lihat gambar 5)

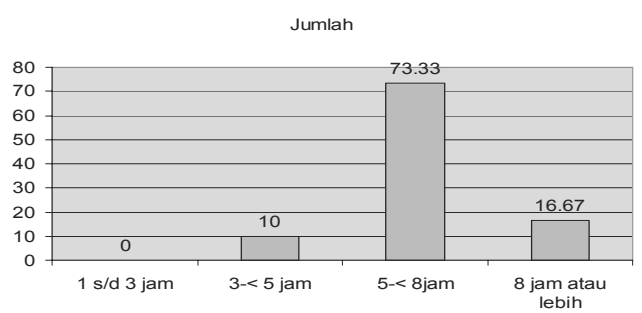

\section{Gambar 5. Curahan Waktu Wanita Pemecah Batu}

Jam kerja yang lebih dari 8 jam berjumlah 16,67 persen, hal ini biasanya mereka sudah bekerja pagi-pagi sekali, karena ada pesanan batu pecahan. Namun demikian jumlah jam kerja yang panjang ini tidak dilakukan setiap hari, hanya kadang-kadang saja.

Curahan waktu yang relatif banyak tersebut, sebenarnya juga tidak mengganggu kegiatan keluarga, seperti mengasuh anak atau kegiatan keluarga yang lainnya. 
Hal ini karena lokasi pekerjaan untuk memecah batu tersebut berada dekat dengan rumahnya. Selain itu pekerjaan tersebut tidak ada sifat pemaksaan waktunya. Mereka dapat bekerja sesuai dengan keinginannya sendiri. Sehingga jika dirasakan ada pekerjaan di rumah atau keperluan lainnya, maka pekerjaan pemecah batu tersebut dapat ditinggal.

\section{KESIMPULAN}

Berdasarkan hasil penelitian yang telah dilakukan dapat diambil beberapa kesimpulan sebagai berikut:

1. Pendapatan yang diperoleh oleh pekerja wanita tersebut menurut mereka dirasakan sudah cukup. Kontribusi pendapatan pekerja wanita terhadap pendapatan suami cukup signifikan.

2. Pendapatan wanita pemecah batu juga merupakan pendapatan keluarga. Penggunaan pendapatan merupakan penggunaan atau belanja untuk kebutuhan keluarga. Penggunaan untuk kebutuhan keluarga tersebut, antara lain untuk mencukupi kebutuhan pokok sehari-hari, untuk kebutuhan sekolah dan juga untuk kebutuhan yang sifatnya sosial, seperti arisan, bowo (menyumbang orang yang punya hajatan).

3. Para wanita pemecah batu ini rata-rata bekerja sebagai pemecah batu sehari selama 5 sampai dengan 8 jam $(73,33$ persen). Namun demikian waktu yang dialokasikan tersebut relatif fleksibel.

Berdasarkan temuan penelitian saran yang dapat disampaikan yaitu adanya pembinaan kemampuan dan keterampilan bagi pekerja wanita, sehingga dapat mengembangkan keterampilan yang lain.
Hal ini karena pekerjaan pemecahan batu tersebut jangka panjang akan merusak lingkungan.

\section{DAFTAR PUSTAKA}

Arjani, Ni Luh. 2002. Gender dan Permasalahannya. Pusat Studi Wanita Universitas Udayana.

Arjani, Ni Luh. 2003. Ketimpangan Gender di Beberapa Bidang Pembangunan di Bali. Jurnal Studi Jender Vol. III No. 2 Tahun 2003

Binaswadaya. 2002. Masalah UKM dan Peran LSM. Buletin 19 Februari 2002.

Effendi, Abbas. 1997. Transformasi Struktural dan Kesejahteraan Masyarakat Pedesaan. Jurnal Populasi. Vol. 8 No. 2

Gilbert, allen dan Gugler, Josef. 1996. Property and Development: Urbanization in the Third World. Terjemahan Anshori. Tiara Wacana Yogyakarta.

Haryono, Suyono.1997. Saatnya Wanita (desa) Terjun ke Dunia Usaha. Warta Demografi Th 27 No. 4.

Indaryani, Mamik. 1997. Peran Wanita dalam Menunjang Ekonomi dalam Rumah Tangga Miskin: Studi Kasus di Kecamatan Selogiri Kabupaten Wonogiri Jawa Tengah. Warta Demografi Th 27. No. 4.

Jenskin, M. 1993. Extending Social Security Protection to the Entire Population: Problem and Issues. International Social Security Review.

Ken, Suratyah dkk. 1994. Marginalisasi Pekerja Wanita di Pedesaan: Studi Kasus pada IRT Pangan di Sulsel. Yogyakarta: PPK UGM. 
Kusdiati,Veronica. 2002. Peran Wanita Konsep Mitra Setara. Sebuah Kajian Teoritik dan Empirik Wanita Pedagang Pasar Tradisional di kota Semarang. Seri Kajian Ilmiah Vol. 11 No. 3.

Lestari, Rahayu Endah. Santoso, Imam. Sulastri, Dwi Rina. 1997. Kontribusi Wanita dalam Agribisnis Gula Semut di Kabupaten Blitar Propinsi Jawa Timur. Jurnal Penelitian Ilmu-Ilmu Sosial Vol. 9 No. 1 Februari.

Mariun, N. Badrun. 2004. Kontribusi Perempuan pada Peningkatan Pendapatan Rumah Tangga Miskin: Studi Kasus di 4 Kabupaten/ Kota. Warta Demografi Tahun 34 No. 3

Setiaji, Bambang. 1996. Wanita Pekerja IRT: Kesejahtaraan dan Perlindungan Hak. Akademika No. 01. Th. XIV Solo: UMS.

Setiawati, Rike dan Amin, Sophia. 2001. Faktor-faktor yang Mempengaruhi Produktivitas Tenaga Kerja Wanita pada Industri Kecil di kota Jambi. Jurnal Pemberdayaan Perempuan Vol. 1 No. 2 Desember.

Setyowati, Yuningtyas. 1996. Pengaruh Tingkat Sosial Ekonomi (SES) Keluarga Terhadap Tingkat Peranan Pencarian Nafkah Karya Penelitian Atmajaya Yogyakarta Edisi 6 tahun VI September.

Sriyuningsih, Niniek. Sekartdji, Kartini. Jadmiko. Dwi Sriyanto. 1998. Diskriminasi terhadap Pekerja Perempuan dalam Kebijakan Manajemen Perusahaan Garmen dan Tekstil di Kotamadya Se- marang. Majalah Penelitian Lembaga Penelitian UNDIP Th X No. 37, Maret.

Subarsono. 1996. Toward Managing the Informal Sector for Urban Economic Development: Government Policy and the Informal Sector. Thesis, the Flinder University of South Australia, Adelaide.

Suprapti, Redjeki, Sri dan Hatatiati. 2001. Pemberdayaan Ibu Rumah Tangga Keluarga Miskin di Pedesaan Kecamatan Mranggen, Kabupaten Demak. Jurnal Pemberdayaan Perempuan Vol. 1. No. 2 Desember.

Tobing, Erwin. 2002. Reorientasi Pembenahan Sektor Informal.

Wibowo, B Junianto. 2002. Profil Wanita Pedagang Kecil di Tinjau dari Aspek Ekonomi (Studi kasus pada Tiga Pasar Tradisional di kota Semarang, yaitu Pasar Gayam, pasar Damar dan pasar Mangkang). Seri Kajian Ilmiah Vol. 11 No. 3

Winarno, Agung. 1996. Profil Usaha Sektor Informal di Jombang. Trisula Jurnal Ilmu Pengetahuan dan Teknologi dan Agama No. 1 Pebruari Universitas Darul Ulum Jombang.

www.theindonesiainstitute.org. Diakses 3 Pebruari 2003.

Yuniarti, Sari dan Haryanto, Sugeng. 2005. Pekerja Wanita pada Industri Rumah Tangga Sandang dan Kontribusinya Terhadap pendapatan Rumah tangga di Kecamatan Sukun Malang. Jurnal Penelitian Universitas Merdeka Malang Vol. XVII Nomor 2 Tahun 2005. 